ORIGINAL ARTICLE

\title{
Personality determinants of motivation to undertake vocational training
}

\author{
Dorota Godlewska-Werner ${ }^{1 \cdot A, B, C, D, E}$, Sylwia Celińska-Nieckarz ${ }^{2 \cdot A, B, D, E, F}$, Zdzisław Nieckarz $z^{3 \cdot B, D, E, F}$, \\ Mariusz Lipowski $i^{4, C, D, F}$ \\ 1: Institute of Psychology, University of Gdansk, Gdansk, Poland \\ 2: Association of Business Coaching, Sopot, Poland \\ 3: Institute of Psychology, University of Gdansk, Gdansk, Poland \\ 4: Department of Health Psychology, University School of Physical Education and Sport, Gdansk, Poland
}

\section{BACKGROUND}

Recently, at a time of frequent changes in the economic and socio-economic circumstances, knowledge acquired in the course of formal education is insufficient. Especially, the education system is still criticized for a lack of flexibility and strong resistance to change. Therefore, regular participation in various forms of training is required. Employee education and training are becoming an optimal answer to complex business challenges. The aim of this study was to determine which personality traits are responsible for the strength of motivation to undertake vocational training and other educational forms.

\section{PARTICIPANTS AND PROCEDURE}

The study included 104 staff members of Polish companies (60 women and 44 men). The study used Cattell's 16 PF Questionnaire and the scales of readiness to undertake training and further education as a measure of the strength of motivation (Kawecka, Łaguna \& Tabor, 2010).
RESULTS

The study showed that openness to change and tension (primary traits) had the greatest impact on the intention and planning to take vocational training. Additionally, the intention and planning to take vocational training were found to be associated with mindedness, independence, self-control, and anxiety (secondary traits). Such traits as rule-consciousness $[\mathrm{G}]$, social-boldness $[\mathrm{H}]$, abstractedness [M], and apprehension [O] (primary traits), were important in some aspects, which could constitute a background for further research and discussion of the results.

\section{CONCLUSIONS}

The obtained results lead to the conclusion that some of the individual differences in personality determine the motivation to undertake vocational training.

\section{KEY WORDS}

personality; vocational training; motivation

CORRESPONDING AUTHOR - Dorota Godlewska-Werner, Institute of Psychology, University of Gdansk, Gdansk, Poland, e-mail: wnsdgw@ug.edu.pl

aUthors' Contribution - A: Study design - B: Data collection - C: Statistical analysis - D: Data interpretation . E: Manuscript preparation · F: Literature search · G: Funds collection

to Cite this ARTICLE - Godlewska-Werner, D., Celińska-Nieckarz, S., Nieckarz, Z. \& Lipowski, M. (2014). Personality determinants of motivation to undertake vocational training. Current Issues in Personality Psychology, 2(1), 38-48. 


\section{BACKGROUND}

Promotion of lifelong learning is a consequence of changes in the attitude towards managing organizations and competencies of their employees (Aspin \& Chapman, 2000). Strong competition, not only of local but also global character, constant market changes and new technologies development are reflected by increased spending on education. This is clear not only for the employers, but also for employees, who undertake various forms of vocational training (London \& Smither, 1999a). Statistical data suggest that incomes of individuals involved in continuous education increase more rapidly than in those who do not show educational activity - this relationship was documented for both 2005 and 2007 (Czapiński \& Panek, 2009).

Self-development, understood as defining ambitious developmental objectives, searching for and utilization of available reverse information and selfmonitoring of progress, becomes a vital component of the career path of every employee (London \& Smither, 1999b). Such an attitude is a key element of efficiency, and reflects the flexibility and adaptive capabilities of employees (Bakker, Demerouti \& ten Brummelhuis, 2012).

Lifelong learning and improvement of professional skills form the basis for evidence-based economy (socio-economic aspect) and effective fulfilment of duties (individual and organizational aspect). Giving priority to professional self-development becomes the manifestation of one's flexibility and willingness to adapt to new constantly changing conditions and professional requirements. However, as documented in the report "Social diagnosis" (Grabowska, Węziak-Białowolska, Kotowska \& Panek, 2013), the situation of the educational activity of Polish adults is not optimistic. First of all, a decrease in the level of educational activity among persons aged between 20 and 29 years was documented (as compared to 2011), and only a slight increase in this parameter (albeit still to a very low level) was observed in a group of individuals older than 30 years; finally, there is no trend for utilizing educational services among people older than 39 years. Moreover, the process of qualification improvement among adults is selective in terms of age, gender, place of residence, education and labour market status, which is reflected by widened competence gaps in regards to various skills, e.g. those associated with novel technologies. As could be expected, the motivation to undertake continuous education represents a serious challenge for a labour market. Without the ability to learn fast, achieving high effectiveness is impossible, both in an individual (a single employee) and an organizational context. Therefore, employees should be reassured that involvement in broadening and strengthening their competencies, including on a self-managed basis, represents an optimal way of planning and execution of their professional career. However, educational activities could not be undertaken without a sufficient level of motivation. Therefore, many researchers have focused on identification of individual and organizational factors that determine the choice of educational objectives, persistence in the learning process, and effects of the latter (Beier \& Kanfer, 2009).

\section{MOTIVATION TO UNDERTAKE TRAINING}

Human motivation can be described in terms of its two basic properties: direction and level, i.e. its power, level and intensity. Power of motivation refers to the ability to focus on achieving a specific objective (result) and overcoming any competitive motivations. The stronger one's motivation, the lower the probability of changing its orientation. Consequently, power of motivation determines the endurance in striving for an objective; in terms of vocational training, this may refer to greater efforts and energy invested in the educational process, strengthening of cognitive processes (e.g. attention, memory), and resultant improvement in the efficiency of learning (Franken, 2006).

According to the self-determination theory, humans possess large resources of cognitive curiosity that drives them to undertake various challenges and development of their skills. People may control their behaviours by defining objectives, planning their execution, and utilization of cognitive abilities. However, activities of an individual have to be driven by his/her intrinsic motivation, in order to make this process effective. The ability to utilize the resources of the latter contribute to the continuation of objective-oriented activities, and lack thereof can stimulate lack of belief in success and lack of control over the learning process (Deci, Vallerand, Pelletier \& Ryan, 1991; Ryan \& Deci, 2000). Autonomy is another factor that determines the choice of intrinsically driven behaviours. The feeling of autonomy (independence and influence) enables one to develop more completely, and makes the process of education more effective. Consequently, one can state that natural human curiosity and the need to satisfy that curiosity can be supported or blocked by a specific social context. Satisfying the need for being competent and the need for autonomy enables one to utilize the resources of intrinsic motivation; this is reflected by better outcomes, e.g. in the process of learning, or during evaluation of work efficiency, the degree of involvement and level of professional satisfaction (Ryan \& Deci, 2000; Baard, Deci \& Ryan, 2004).

Motivation to undertake educational activities is one of the components of active learning, i.e. self-undertaken behaviours aimed at improvement 
of competencies required at a workplace (London \& Smither, 1999b). The remaining two components of the active learning process are the ability to control the learning process and experiencing self-efficacy during training (Bakker et al., 2012). Active attitude of an employee towards his/her professional status not only includes the analysis of a present situation, but also prediction and prevention of potential problems, and utilization of available opportunities. The sense of self-efficacy, possibility of controlling a situation, and low costs of undertaken activities enhance motivation and inclination to proactive behaviours (Parker, Bindl \& Strauss, 2010). Moreover, the active attitude to the process of gaining new skills allows employees better control of their workplaces. Due to newly gained competencies, they can change not only the quality or way of performing their tasks, but also the extent and character of interactions with their co-workers; this enriches both them and the process of work. Consequently, the development of an employee can be an instrument of change, both for himself/herself and for his/her environment (Wrześniewski \& Dutton, 2001); simultaneously it satisfies the need for building relationships with others, which is one of the fundamental needs of a human being (Ryan \& Deci, 2000).

Moreover, the motivation to undertake educational activities is one of the variables that determine effectiveness of educational activities (Mathieu \& Martineau, 1997). This is not an equivalent of the attitude to the training; it refers to the general attitude to participation in training, rather than to the attractive programme of a specific course. The motivation to undertake training is comprised of three variables: attitude to training, motivation for learning, and transfer motivation (Rowold, 2007). Research proved that motivation to undertake training, defined as the degree of involvement in the educational process, in order to gain knowledge and experience, is significantly positively correlated with motivation for achievements, organizational involvement and attitude to training; in contrast, the motivation to undertake training is not modulated by the sense of self-efficacy (Carlson, Bozeman, Kacmar, Wright \& McMahan, 2000).

Employees start and complete training with various levels of motivation, which is determined by their personality traits and past experiences; in turn, the level of motivation determines the amount of knowledge gained during courses and the way of its future utilization (Mathieu \& Martineau, 1997). Furthermore, it is motivation that determines the behaviour during training, way of learning, and the usefulness of the gained competencies. Identification of factors that determine the motivation to undertake training is important, as stronger motivation is reflected by better performance at work, implemented due to newly gained knowledge (Rowold, 2007).
Moreover, the motivation to learn is also modulated by social cues associated with co-workers' and supervisors' views on the usefulness of training (Morrell \& Korsgaard, 2011).

\section{VOCATIONAL TRAINING}

Vocational training is a process aimed at development of professional competencies that are necessary for performing a specific job. The training is a component of professional development oriented at gaining knowledge which can be useful both at the present workplace and in the context of potential promotion, shift to a different position or organizational changes (Nieckarz, Celińska-Nieckarz \& Godlewska-Werner, in press). Vocational training not only prepares one for performing specific work in a newly learned profession, but is also aimed at the development of soft skills, e.g. social skills supporting optimal functioning within a working team. Presently, employees have more opportunities to develop their competencies and gain knowledge; moreover, the level of responsibility for this process has increased (Bertolino, Truxillo \& Fraccaroli, 2011). However, involvement in voluntary training requires spending some time, not only for finding an appropriate course but also for planning participation in the classes; this can frequently interfere with professional duties (Colquitt, LePine \& Noe, 2000).

In view of the developing idea of lifelong learning, one should note that undertaking educational activity may exert a considerable impact on the management of employee development within an organization. Vocational training should not be based solely on employer-undertaken initiatives (training, courses, etc.). The foundation of learning organizations is self-reliance of their employees in undertaking educational initiatives; these activities may markedly contribute to an increase in the worth of the entire company. However, achieving desired outcomes of such activities requires development of certain strategies within an organization in order to support its employees' self-development; examples of such strategies include evaluation of training effects or usefulness of newly gained knowledge for the realization of professional duties (Smith, Robertson \& Wakefield, 2002).

Such activities are vitally important, especially in the context of vocational training aimed at gaining and updating the knowledge that is necessary for executing one's professional duties. Research showed that frequently employers could not provide appropriate conditions and support for undertaking educational initiatives, even if they offer varied forms of education. For example, the number of Polish companies that organized training for their employees corresponded to $41.4 \%$ of all business entities. However, 
large companies mostly organize training, whereas the participation of small companies corresponded to $36.4 \%$ (Report "Education of Adults" 2005). Defining an education strategy based on the assumptions of the self-standing theory should constitute a challenge for an organization. In such a strategy, each employee should be able to utilize his/her skills to identify and achieve his/her own educational objectives, and satisfy his/her need for autonomy and competencies (Smith, 2003).

The decision to participate in training is driven by individual variables, organizational factors, and aspects associated with the process of learning (Wang \& Wang, 2004). The most frequent motifs behind undertaking developmental activity include the possibility of promotion, increase in salary or changing job (Nieckarz et al., in press). However, the reasons for undertaking educational activities vary depending on gender, age, and the type of training (Godlewska-Werner, 2012). For example, individuals between 25 and 34 years of age get involved in training in order to change their job, whereas persons older than 46 years decide to participate in various forms of vocational training due to pressures from their supervisors or for personal interest (Nieckarz et al., in press). Younger employees are eager to participate in professional training as they expect to achieve predefined objectives associated with their career paths (Bertolino et al., 2011). As many as $42 \%$ of the surveyed adults beginning part-time education undertook the training in order to find a job; another $31 \%$ wanted to improve their qualifications, and $15 \%$ hoped to change their jobs (Wyrzykowski, 2000).

\section{PERSONALITY DETERMINANTS OF MOTIVATION TO UNDERTAKE TRAINING}

Individual differences determine the motivation to learn and involvement in training. Moreover, they exert an indirect effect on undertaking educational activity (Major, Turner \& Fletcher, 2006). The probability of undertaking training increases proportionally to the motivation for continuous education (Theranou, 2001). The readiness to undertake training is composed of two components: intention to continue education, and an accurate plan regarding time and place of beginning the process, i.e. implementation intention (Kawecka et al., 2010). Research showed that defining a specific educational plan stimulates decisions on involvement in learning within the next two years (Brandstätter, Heimbeck, Malzacher \& Frese, 2003). From the occupational perspective, participation in training represents one of the behaviours that are oriented at achieving specific objectives associated with a professional career, e.g. promotion. Therefore, perceiving an objective as attractive and achievable promotes the readiness for activities oriented at this goal, the intention to undertake them, and planning specific actions (Eaguna, 2012).

The amount of published research on personality-related determinants of readiness to undertake training is small. Analysis of the available resources showed that many of the studies dealt with personality traits associated with the "Big Five" theory. Rowold (2007) found that extraversion alone could be associated with motivation to undertake training, whereas extraversion and agreeableness promote motivation for learning, and extraversion and emotional stability promote transfer motivation. Another study showed that motivation for learning is associated with proactive personality, openness to experience, extraversion and conscientiousness (Major et al., 2006). Undertaking developmental activities can be modulated by such personality traits as conscientiousness (Colquitt, et al.) or the levels of extraversion and emotional stability (Wyrzykowski, 2000). Motivation for learning and readiness for voluntary participation in training are associated with the level of conscientiousness (Colquitt et al., 2000; Morrell \& Korsgaard, 2011). Barrick and Mount (1991) found that Openness and Extraversion are related to performance in training programmes. Kucharski (2004) ascertained that personality traits measured by the 16 PF Questionnaire have a significant impact on behaviour. The psychological importance of each factor is based on its relationship with other variables. For undertaking developmental activities features such as Liveliness (F), Social Boldness $(\mathrm{H})$, or Openness to Change (Q1) may be important. For example, Liveliness correlates with the Personality Research Form's Play, Affiliation and Exhibition scales; with CPI's Sociability, Social Presence, Empathy and Self-Acceptance scales; and with all of the NEO's Extraversion facets. A high score in the Social Boldness scale helps in challenging and stressful situations (e.g. social exposure during training). Scale $\mathrm{H}$ correlates with the CPI's Sociability and Social Presence scales and with the NEO's Extraversion dimension. Scale Q1 correlates positively with all six of the NEO's Openness facets. It correlates with the PRF's need for Change and Understanding and with the CPI's Tolerance, Intellectual Efficiency, and Achievement scales. The high scorers like to think openly, without barriers, and enjoy experimenting in new and atypical solutions (Cattell \& Schuerger, 2003). Therefore, knowledge of personality traits allows one to predict the level of motivation to undertake developmental activities (Eaguna, 2012). According to Rowold (2007), personality explains about $20 \%$ of the motivation to undertake training.

Participating in educational activities is associated with intentional actions of individuals. Researchers have suggested that people who are highly involved with their jobs are more likely to be motivated, be- 
cause participation in training can increase skill levels and improve job performance (Major et al., 2006; Theranou, 2001). The research conducted by Łaguna (2012) showed that personality traits modulate various stages of processes associated with undertaking educational activities. Moreover, perception of an objective as attractive and achievable promotes the readiness for activities oriented at this goal: intention to undertake them and planning of specific activities. Statistical analyses showed that intention to undertake training is modulated by agreeableness and openness to experience, and emotional stability, extraversion and openness to experience influence one's evaluation of chances for undertaking and completing a training course, which is in turn associated with implementation intention. Furthermore, low level of emotional stability decreases the probability of undertaking and completing training, and conscientiousness determines the assessment of the role ascribed to undertaken developmental activities. Another study revealed that goal-oriented learning is positively correlated with conscientiousness, and shows an inverse correlation with emotional stability (Brown \& O’Donnell, 2011).

Based on above-mentioned studies our main research hypotheses are as follow:

Hypothesis 1a: Primary traits will correlate with the intent to undertake vocational training and other forms of education.

Hypothesis 1b: Secondary traits will correlate with the intent to undertake vocational training and other forms of education.

Hypothesis 2a: Primary traits will correlate with the planning to undertake vocational training and other forms of education.

Hypothesis 2b: Secondary traits will correlate with the planning to undertake vocational training and other forms of education.

\section{PARTICIPANTS AND PROCEDURE}

The studied group consisted of 104 persons, employees of Polish companies (60 women and 44 men), aged from 24 to 61 years $(M=34.6$ years). Forty-six participants occupied managerial positions (22 women and 24 men) and remaining employees occupied non-manager positions (38 women and 20 men). The study used the 'Intention to Take Training Scale' and 'Planning to Take Training Scale' developed by Kawecka et al. (2010), and Cattell's 16 PF Questionnaire. The scales were characterized as highly reliable, with Cronbach's alpha ranging between 0.91 and 0.94 (Kawecka et al., 2010). All items were scored according to the 5-point Likert scale, ranging from 'definitely not' (1) to 'definitely yes' (5). The reliability (Cronbach's $\alpha$ ) of the individual subscales of the 16 PF Questionnaire, determined in the Polish sample, ranged from 0.64 to 0.85 (Kucharski, 2004).

\section{RESULTS}

Analysis of correlation (Pearson $r$ coefficients) showed that there were statistically significant associations between some of the primary traits of personality and the various components of motivation to undertake vocational training. The results showed that there was a significant correlation between intention to participate in training and tension [Q4] (-0.21), intention to participate in other forms of education and openness to change [Q1] (0.24), planning to undertake training and openness to change [Q1] (0.23), planning to undertake other educational forms and openness to change [Q1] (0.32), abstractedness [M] (0.23), social boldness $[\mathrm{H}](0.22)$, and apprehension [O] (-0.22). All correlations were significant $(p<0.05)$ (Table 1$)$.

Additionally, relationships between the secondary traits of personality factors and components of motivation to undertake vocational training were reported (Table 2). It appears that there is a correlation

Table 1

Significant correlations between the primary traits of personality and motivation to undertake vocational training

\begin{tabular}{ccc}
\hline Intention and plan & Primary personality factors & $r$ \\
\hline Intention to participate in training & Tension (Q4) & $-0.21^{*}$ \\
Intention to participate in other education forms & Openness to change (Q1) & $0.24^{*}$ \\
Planning to undertake training & Openness to change (Q1) & $0.23^{*}$ \\
& Openness to change (Q1) & $0.32^{*}$ \\
Planning to undertake other education forms & Abstractedness (M) & $0.23^{*}$ \\
& Social boldness (H) & $0.22^{*}$ \\
\hline
\end{tabular}

Note. ${ }^{*} p<0.05$. 
Table 2

Significant correlations between the secondary traits of personality and motivation to undertake vocational training

\begin{tabular}{ccc}
\hline Intention and plan & Global personality factors & $r$ \\
\hline & Tough-mindedness & $0.21^{*}$ \\
Intention to participate in other education forms & Independence & $0.21^{*}$ \\
& Self-control & $0.26^{*}$ \\
Planning to undertake training & Tough-mindedness & $0.37^{*}$ \\
& Independence & $0.29^{*}$ \\
Planning to undertake other education forms & Self-control & $0.21^{*}$ \\
& & $-0.23^{*}$ \\
& Anxiety & $0.32^{*}$ \\
& Tough-mindedness & $0.30^{*}$ \\
\hline
\end{tabular}

Note. ${ }^{*} p<0.05$.

Table 3

Primary personality traits explaining motivation to undertake vocational training

\begin{tabular}{|c|c|c|c|}
\hline Intention and plan & Multiple $R^{2}$ & $\begin{array}{c}\text { Primary traits which explain } \\
\text { the model }\end{array}$ & $\beta$ \\
\hline Intention to participate in training & $\begin{array}{c}0.04 \\
p=0.03\end{array}$ & Tension (Q4) & $\begin{array}{l}\beta=-0.21 \\
p=0.03\end{array}$ \\
\hline $\begin{array}{l}\text { Intention to participate in other } \\
\text { education forms }\end{array}$ & $\begin{array}{c}0.10 \\
p=0.006\end{array}$ & $\begin{array}{l}\text { Rule-consciousness (G) } \\
\text { Openness to change (Q1) }\end{array}$ & $\begin{array}{l}\beta=0.20 \\
p=0.04 \\
\beta=0.27 \\
p=0.006\end{array}$ \\
\hline Planning to undertake training & $\begin{array}{c}0.11 \\
p=0.0005\end{array}$ & Openness to change (Q1) & $\begin{array}{l}\beta=0.34 \\
p=0.0005\end{array}$ \\
\hline $\begin{array}{l}\text { Planning to undertake other education } \\
\text { forms }\end{array}$ & $\begin{array}{c}0.11 \\
p=0.001\end{array}$ & Openness to change (Q1) & $\begin{array}{l}\beta=0.32 \\
p=0.001\end{array}$ \\
\hline
\end{tabular}

between intention to participate in other forms of education and self-control (0.26), tough-mindedness, and also independence (both 0.21). Planning to undertake training corresponded to tough-mindedness (0.37), independence (0.29), and self-control (0.21), and planning to undertake other forms of education was associated with tough-mindedness (0.32), independence (0.30), self-control (0.24) and anxiety $(-0.23)$. All correlations were significant $(p<0.05)$.

The linear regression analysis showed that some primary personality traits explained motivation to undertake vocational training (Table 3 ).

Tension [Q4] explained only $4 \%$ of the intention to participate in training $(\beta=-0.21 ; p=0.03)$. Personality explained $10 \%$ of the intention to participate in other forms of education by two factors: rule-consciousness [G] $(\beta=0.20 ; p=0.04)$ and openness to change [Q1] $(\beta=0.27 ; p=0.006)$. In this study, openness to change [Q1] explained $11 \%$ of planning to undertake training $(\beta=0.34 ; p=0.0005)$ and planning to undertake other forms of education $(\beta=0.32 ; p=0.001)$.

Secondary personality traits did not explain the intention to participate in training (Table 4). Intention to participate in other forms of education was explained by $7 \%$ of such secondary personality traits as self-control $(\beta=0.26 ; p=0.007)$. Planning to undertake training was explained by $13 \%$ of tough-mindedness $(\beta=$ $=0.37 ; p=0.0001)$. Secondary personality traits, such as anxiety $(\beta=-0.20 ; p=0.04)$ and tough-mindedness $(\beta=0.30 ; p=0.002)$, explained $14 \%$ of planning to undertake other forms of education.

It is also assumed that personality is treated as a variable serving as a mediator in the correlation between intentions to undertake training/to continue other education forms and planning both activities. In order to assess the mediating role of personality in the development of correlations between intentions and plans, the researchers conducted an analysis as- 
Table 4

Secondary personality traits explaining motivation to undertake vocational training

\begin{tabular}{cccc}
\hline Intention and plan & Multiple $R^{2}$ & $\begin{array}{c}\text { Global factors which explain } \\
\text { the model }\end{array}$ & $\beta$ \\
\hline $\begin{array}{c}\text { Intention to participate in other educa- } \\
\text { tion forms }\end{array}$ & $\begin{array}{c}0.07 \\
p=0.007\end{array}$ & Self-control & $\begin{array}{l}\beta=0.26 \\
p=0.007\end{array}$ \\
Planning to undertake training & 0.13 & Tough-mindedness & $\beta=0.37$ \\
& $p=0.0001$ & & $p=0.0001$ \\
Plan to undertake other education forms & 0.14 & Anxiety & $\beta=-0.20$ \\
& $p=0.0004$ & Tough-mindedness & $p=0.04$ \\
& & & $p=0.30$ \\
\end{tabular}

Table 5

Intention to participate in training and planning to undertake training - the mediating role of personality

\begin{tabular}{|c|c|c|c|c|c|c|c|c|c|}
\hline \multirow[t]{3}{*}{ Mediator } & \multicolumn{8}{|c|}{ Participate in training } & \multirow[t]{3}{*}{$x$} \\
\hline & \multicolumn{4}{|c|}{ Direct } & \multicolumn{4}{|c|}{ Indirect } & \\
\hline & $\beta$ & LB & UB & $p$ & $\beta$ & LB & UB & $p$ & \\
\hline Extraversion & 0.824 & 0.751 & 0.878 & 0.01 & 0.006 & 0.027 & 0.038 & 0.822 & $<0.001$ \\
\hline Anxiety & 0.231 & -0.179 & 0.483 & 0.264 & 0.42 & 0.188 & 0.829 & 0.01 & 0.42 \\
\hline Mindedness & -0.019 & -0.34 & 0.721 & 0.587 & -0.76 & 0.102 & 0.997 & 0.001 & 0.95 \\
\hline Independence & 0.218 & 0.242 & 0.67 & 0.395 & 0.447 & 0.111 & 0.896 & 0.001 & 0.45 \\
\hline Self-control & -0.71 & -0.279 & 0.442 & 0.982 & -0.721 & 0.223 & 0.921 & 0.01 & 0.25 \\
\hline
\end{tabular}

Note. LB - lower bound of confidence interval; UB - upper bound of confidence interval.

Table 6

Intention to continue education and planning the details of the learning process - the mediating role of personality

\begin{tabular}{|c|c|c|c|c|c|c|c|c|c|}
\hline \multirow[t]{3}{*}{ Mediator } & \multicolumn{8}{|c|}{ Continue other education forms } & \multirow[t]{3}{*}{$x$} \\
\hline & \multicolumn{4}{|c|}{ Direct } & \multicolumn{4}{|c|}{ Indirect } & \\
\hline & $\beta$ & LB & UB & $p$ & $\beta$ & LB & UB & $p$ & \\
\hline Extraversion & 0.714 & 0.606 & 0.805 & 0.01 & 0.009 & -0.067 & 0.13 & 0.479 & $<0.001$ \\
\hline Anxiety & 0.76 & -0.199 & 0.342 & 0.642 & 0.264 & 0.089 & 0.533 & 0.01 & 0.07 \\
\hline Mindedness & 0.207 & -0.133 & 0.504 & 0.214 & 0.191 & -0.045 & 0.617 & 0.084 & 0.23 \\
\hline Independence & 0.119 & 0.108 & 0.467 & 0.20 & 0.226 & 0.008 & 0.487 & 0.058 & 0.43 \\
\hline Self-control & 0.177 & -0.169 & 0.352 & 0.24 & 0.157 & 0.77 & 0.492 & 0.01 & 0.22 \\
\hline
\end{tabular}

Note. LB - lower bound of confidence interval; UB - upper bound of confidence interval.

sessing the significance of direct effects and indirect effects through a 1000 -fold bootstrap simulation. The results of the analysis are presented in Tables 5 and 6 .

Results in Table 5 and 6 showed that there are full mediations of the variable anxiety, tough-mindedness, independence and self-control with regard to the correlation of intention to participate in training and planning to undertake training. Thus, one can state that whether intention to undertake vocational training will change into a plan to do so depends on anxiety, tough-mindedness, independence and self-control. There were also full mediations of the variable tough-mindedness, independence and self-control with regard to the correlation of intention to continue other education forms and planning to undertake training. These results indicated that 
tough-mindedness, independence and self-control mediate between intention to continue education and planning details of the learning process.

Therefore, the hypotheses were only partially confirmed. Only some of the primary and secondary traits were related to the motivation to undertake vocational training.

\section{DISCUSSION}

The motivation to undertake vocational training and the level of commitment to training depend on the specific personality traits (Major et al., 2006). Personality is found in many motivation theories as it creates differences in self-set goals. Some traits are often examined (e.g. the Big Five) while others have been explored only in a few studies. This study allowed the differentiation of some primary and secondary personality traits explaining the intention to participate in training and other forms of education and planning to undertake training and other forms of education. Disastrously, the results were not satisfactory and will require confirmation.

Statistical analyses showed that there was a correlation between tension [Q4] and intention to participate in training. A negative correlation means that high tension [Q4] was associated with lesser involvement in vocational training. According to Cattell's concept, a high level of tension [Q4] can negatively affect self-control and effectiveness of action. Moreover, individuals who score higher on the scale are more prone to irritation, e.g. due to changing plans or behaviours of others. The results did not fully explain the association with intention to participate in training, as Cattell showed that demotivation results from low, rather than high levels of tension. Individuals showing low levels of tension like comfort, and may not be eager for changes and self-mobilization (Kucharski, 2004; Cattell \& Schuerger, 2003). Moreover, results were not consistent with the results of previous studies dealing with readiness to undertake training. Łaguna (2012) observed an association between agreeableness and openness to experience in the context of intention to participate in training, and Rowold (2007) documented a relation between emotional stability and transfer motivation. Tension can explain variance in the intention to participate in training to some degree, but the power of this relationship is unsatisfactory. The study did not reveal an association between the intention to participate in training and other personality traits. Moreover, tension did not explain the variance in intention to participate in training at a satisfactory level.

Intention to participate in other educational forms correlated with openness to change [Q1] (primary trait), and tough-mindedness, independence and self-control (secondary traits). The discussed variable was jointly explained by rule-consciousness [G] and openness to change [Q1]. It means that employees focused on respecting certain social principles, and showing flexibility in making changes, may have a greater incentive to participate in various forms of learning. Rule-consciousness [G] was defined by being careful with a significant tendency to do tasks well because of others' expectations (Kucharski, 2004). Consequently, individuals characterized by high levels of rule-consciousness [G] show greater readiness to undertake various forms of educational activities, thus creating their image and following opinions perceived in their environment, e.g. on the necessity of lifelong learning. Moreover, rule-consciousness [G] correlates positively with such traits as self-control (secondary trait), liveliness [F], abstractedness [M] and perfectionism [Q3] (primary traits), which may promote behaviours that are considered socially appropriate (Kucharski, 2004; Cattell \& Schuerger, 2003). Studies of factors associated with the "Big Five" theory and "NEO-PI-R" revealed an association between conscientiousness, whose definition resembles that of the self-control trait (Cattell \& Mead, 2008) and importance ascribed to undertaken training (Eaguna, 2012) or motivation for learning (Colquitt et al., 2000; Morrell \& Korsgaard, 2011). Another personality trait that is associated with intention to participate in other educational forms can be described as a tendency of an individual to seek new ways of improvement, being associated with flexibility and a critical attitude to problems (Kucharski, 2004). Open persons are more prone to implement changes whenever they find their situation unsatisfactory. Therefore openness to change supports the intention to undertake various educational forms, as well as development of specific plans regarding time and place of these activities. This finding is consistent with the results published by Łaguna (2012), who documented the effect of openness to experience on intention and implementation intention, and observations of Major et al. (2006) on the influence of openness to experience on motivation for learning. Intention to participate in other forms of education was explained by such secondary personality trait as self-control. A high level of self-control was associated with such traits as rule-consciousness [G], liveliness [F], abstractedness $[\mathrm{M}]$ and perfectionism [Q3]. This is reflected by the presence of strong social desire; in other words, an individual is strongly motivated by perceived social standards and strives to follow and fulfil them. Such a person is also more disciplined and better organized (association with perfectionism) and practically oriented (association with abstractedness) (Cattell \& Mead, 2008). No analyses of association between self-control and motivation to undertake training have been published to date. 
Planning to undertake training correlated with openness to change [Q1] and tough-mindedness, independence, and self-control. The second variable, planning to undertake other forms of education, correlated with openness to change [Q1], abstractedness $[\mathrm{M}]$, social boldness $[\mathrm{H}]$, apprehension [O] and anxiety, tough-mindedness, independence, and self-control. Planning to undertake training and planning to undertake other forms of education were explained by such a secondary trait as tough-mindedness. Tough-mindedness is characterized by cold calculation of a situation and promotes making evidence-based decisions. Individuals presenting high levels of this trait are practically oriented and specific. Nevertheless, they are not open to changes and may have problems with accepting new points of view (Kucharski, 2004; Cattell \& Schuerger, 2003). The results illustrated that some traits associated with cold rationalism support the process of planning, e.g. with regards to activities associated with undertaking training, but simultaneously may reduce openness of an individual to new experiences, e.g. associated with the necessity of learning new behaviours or gaining new skills.

Additionally, planning to undertake other forms of education was explained by such a secondary trait as anxiety. Low scores on the anxiety scale correspond to maturity, confidence, self-reliance and adaptive abilities (Kucharski, 2004; Cattell \& Schuerger, 2003). Persons with such scores are not reluctant to undertake developmental activities as they are not too susceptible to extrinsic (e.g. the opinions of others) or intrinsic (e.g. excessive mistrust) anxiety-related factors. It is gaining new experiences, rather than anxiety, which drives their activities. Wyrzykowski (2000) documented the effect of neuroticism on undertaking education activities. Also Łaguna (2012) emphasized that neuroticism reduces chances for completing education.

Finally, it should be stressed that statistical analysis showed that extraversion, considered the secondary trait, does not explain any of the components of motivation for undertaking and planning training or other developmental activities. Such lack of association was not reported in any previous studies dealing with the problem in question (Eaguna, 2012; Rowold, 2007; Major et al., 2006; Wyrzykowski, 2000).

The knowledge about personality factors which influence planning details of learning or training processes is very crucial because it allows one to predict who would really benefit from the education process. According to Brandstätter et al. (2003), defined educational plans result in undertaking training or other learning forms within the next two years. This means that willingness to learn is not enough - it should be further specified. Analysis of results indicated that anxiety, tough-mindedness, independence and self-control mediated between intention to under- take training and planning to participate in training. The only insignificant variable was extraversion, which was contrary to results obtained by others (e.g. Major et al., 2006; Rowold, 2007). Łaguna (2012) indicated that emotional stability, extraversion and openness to change determine chances for undertaking and completing training courses. The conducted research partially confirmed these studies, whereas, according to the statistical results, tough-mindedness, independence and self-control influenced planning the details of the learning process.

The present investigation offers tentative evidence for hypotheses and paves the way for future research. It is therefore important to know what personality traits determine the strength of motivation for vocational training. There are several important reasons. Employee training and development entail not only obtaining new knowledge and skills, but also the possibility to support entrepreneurship, and introduce employees to changes and important business decisions.

\section{CONCLUSIONS}

The obtained results lead to the conclusion that some of the primary and secondary traits had an impact on the strength of motivation to undertake vocational training. The results showed that the factors having the greatest impact on the intention and plan to undertake a vocational training programme were openness to change, mindedness, independence and self-control. In addition, having a plan was influenced by low anxiety. Such factors as rule-consciousness and social boldness were important in some aspects. The study did not confirm the correlation between extraversion and strength of motivation, which was shown in other studies. Future research should focus on other aspects of personality.

A number of studies of the determinants of motivation to undertake training focused on proactive personalities. Proactive personality is characterized by a tendency to seek and identify new possibilities (Seibert, Crant \& Krainer, 1999). Being proactive is associated with courage in undertaking activities aimed at improvement of one's situation, and thus increases chances for professional success, contrary to reactive persons, who do not create reality but respond to it. Proactive personality determines effectiveness of one's activities due to undertaking initiative associated with execution of tasks (Brown \& O’Donnell, 2011). One study revealed that the more proactive the employees, the greater their motivation for training, as they associate the latter with the possibility of organization development. The same study showed an association between motivation and intention to undertake training and proactive personality; however, this relationship turned out to 
be stronger in the case of younger employees (Bertolino et al., 2011). Many components of proactivity are strongly correlated with extraversion, agreeability, conscientiousness and neuroticism. In contrast, none of the components of proactive personality showed a significant correlation with openness to experience (Hambrick \& McCord, 2010). Major et al. (2006) found an association between proactive personality and neuroticism, extraversion, openness to experience and conscientiousness. In view of these findings, proactive personality may constitute an interesting object of research.

Results were presented as a poster at the International Conference "Motivation in Social Context", 30 fune 2013 - 2 fuly 2013, Cracow.

\section{RefERENCES}

Aspin, D.N. \& Chapman, J.D. (2000). Lifelong learning: concepts and conceptions. International Journal of Lifelong Education, 19, 2-19.

Baard, P.P., Deci, E.L. \& Ryan, R.M. (2004). Intrinsic need satisfaction: A motivational basis of performance and well being in two work settings. Journal of Applied Social Psychology, 34, 2045-2068.

Bakker, A.B., Demerouti, E. \& ten Brummelhuis, L.L. (2012). Work engagement, performance, and active learning: The role of conscientiousness. Journal of Vocational Behavior, 80, 555-564.

Barrick, M.R. \& Mount, M.K. (1991). The Big Five personality dimensions and job performance: meta-analysis. Personnel Psychology, 44, 1-26.

Beier, M.E. \& Kanfer, R. (2009). Motivation in training and development: A phase perspective. In: S.W.J. Kozlowski \& E. Salas (eds.). Learning, Training, and Development in Organizations (pp. 65-97). New York: Psychology Press.

Bertolino, M., Truxillo, D.M. \& Fraccaroli, F. (2011). Age as moderator of the relationship of proactive personality with training motivation, perceived career development from training, and training behavioral intentions. Journal of Organizational Behavior, 32, 248-263.

Brandstätter, V., Heimbeck, D., Malzacher, J.T. \& Frese, M. (2003). Goals need implementation intentions: The model of action phases tested in the applied setting of continuing education. European Journal of Work and Organizational Psychology, 12, 37-59.

Brown, S. \& O’Donnell, E. (2011). Proactive personality and goal orientation: A model of directed effort. Journal of Organizational Culture, Communications and Conflict, 15, 103-119.

Carlson, D.S., Bozeman, D.P., Kacmar, K.M., Wright, P.M. \& McMahan, G.C. (2000). Training motivation in organizations: An analysis of individual- level antecedents. Journal of Managerial Issues, 12, 271-287.

Cattell, H.E.P. \& Mead, A.D. (2008). The Sixteen personality factor questionnaire. In: G.J. Boyle, G. Matthews \& D.H. Saflofske (eds.). The SAGE Handbook of Personality Theory and Assessment. Personality Measurement and Testing. (Vol. 2, pp. 135-159). International: Sage Ltd.

Cattell, H.E.P. \& Schuerger, J.M. (2003). Essentials of 16PF Assessment. Hoboken: John Wiley \& Sons.

Colquitt, J.A., LePine, J.A. \& Noe R.A. (2000). Toward an integrative theory of training motivation: a meta-analytic path analysis of 20 years of research. The Journal of Applied Psychology, 85, 678-707.

Czapiński, J. \& Panek, T. (2011). Diagnoza Społeczna 2011. Warunki i jakość życia Polaków [Social Diagnosis 2011. Conditions nad quality of Poles' life]. Warszawa: Rada Monitoringu Społecznego.

Deci, E.L., Vallerand, R.J., Pelletier, L.G. \& Ryan, R.M. (1991). Motivation and education: The self-determination perspective. The Educational Psychologist, 26, 325-334.

Franken, R.E. (2006). Psychologia motywacji [Psychology of motivation]. Gdańsk: GWP.

Godlewska-Werner, D. (2012). Komu chce się uczyć, czyli motywacje uczestników szkoleń [Who wants to learn. Trainees' motivation]. In: A. StankiewiczMróz \& J.P. Lendzion (eds.). Jakość zarządzania zasobami ludzkimi we wspótczesnych organizacjach [The quality of Human Resorces Management in modern organizations] (pp. 65-81). Łódź: Politechnika Łódzka.

Grabowska, I., Węziak-Białowolska, D., Kotowska, I.E. \& Panek, T. (2013). Edukacja i kapitał ludzki [The education and human capital]. In: J. Czapiński \& T. Panek (eds.). Diagnoza spoteczna 2013 [Social Diagnosis 2013] (pp. 91-109). Retrived 08.02.2014 from: www.diagnoza.com.

Hambrick, E.P. \& McCord, D.M. (2010). Proactive coping and its relation to the five-factor model of personality. Individual Differences Research, 8, 67-77.

Kawecka, K., Łaguna, M. \& Tabor, K. (2010). Gotowość do podejmowania szkoleń i dalszego kształcenia. Propozycja ujęcia teoretycznego i skal pomiaru [The readiness to undertake vocational trainings and other education activities. The proposition of teoretical approach and measurement scales]. Organizacja i Kierowanie, 2, 43-55.

Kucharski, T. (2004). Wprowadzenie do Kwestionariusza 16 PF-5 [Intoduction to the 16 PF-5 Questionnaire]. Toruń: Wydawnictwo Adam Marszałek.

London, M. \& Smither, J.W. (1999a). Career-related continuous learning: Defining the construct and mapping the process. Research in Personnel and Human Resources Management, 17, 81-121.

London, M. \& Smither, J.W. (1999b). Empowered self-development and continuous learning. Human Resource Management, 38, 3-15. 
Łaguna, M. (2012). Cechy osobowości a podejmowanie działań rozwojowych przez pracowników [The personality traits and employees' educational activities]. Czasopismo Psychologiczne, 18, 277-285.

Major, D.A., Turner, J.E. \& Fletcher, T.D. (2006). Linking proactive personality and the Big Five to motivation to learn and development activity. Journal of Applied Psychology, 91, 927-935.

Mathieu, J.E. \& Martineau, J.W. (1997). Individual and situational influences on training motivation. In: J.K. Ford, S.W.J. Kozlowski, K. Kraiger, E. Salas \& M.S. Teachout (eds.). Improving training effectiveness in work organizations (pp. 193-221). New York: Taylor \& Francis.

Morrell, D.L. \& Korsgaard, M.A. (2011). Training in context: Toward the person-by-situation view of voluntary training. Human Resource Development Quarterly, 22, 323-342.

Nieckarz, Z., Celińska-Nieckarz, S. \& GodlewskaWerner, D. (in press). Rozwój zawodowy a priorytety i oczekiwania edukacyjne w różnych grupach wiekowych [The vocational development, priorities and educational expectations in various groups].

Parker, S.K., Bindl, U.K. \& Strauss, K. (2010). Making things happen: A model of proactive motivation. Journal of Management, 36, 827-856.

Raport "Uczenie się dorosłych" [Raport "Adults' learning”] (2005). http://www.mpips.gov.pl/ [08.02. 2014]

Rowold, J. (2007). The impact of personality on training-related aspects of motivation: Test of a longitudinal model. Human Resource Development Quarterly, 18, 9-31.

Ryan, R.M. \& Deci, E.L. (2000). Self-determination theory and the facilitation of intrinsic motivation, social development and well-being. American Psychologist, 55, 68-78.

Seibert, S.E., Crant, J.M. \& Krainer, M.L. (1999). Proactive personality and career success. Journal of Applied Psychology, 84, 416-427.

Smith, P.J. (2003). Workplace learning and flexible delivery. Review of Educational Research, 73, 53-88.

Smith, P.J., Robertson, I. \& Wakefield, L. (2002). Developing preparedness for flexible delivery of training in enterprises. Journal of Workplace Learning, 14, 222-232.

Theranou, P. (2001). The relationship of training motivation to participation in training and development. Journal of Occupational and Organizational Psychology, 74, 599-621.

Wang, G.G. \& Wang, J. (2004). Toward a theory of human resource development learning participation. Human Resource Development Review, 3, 326-353.

Wrześniewski, A. \& Dutton, J.E. (2001). Crafting a job: Revisioning employees as active crafters of their work. Academy of Management Review, 26, 179-201. Wyrzykowski, P. (2000). Cechy osobowości dorosłych rozpoczynających naukę w szkole zaocznej [Perso- nality traits of adults starting extramural school]. In: J. Saran (eds.). Edukacja dorostych. Teoria i praktyka w okresie przemian [Education of adults. Theory nad practice in transition] (pp. 283-290). Lublin: Wydawnictwo UMSCS. 